\title{
Secularization, Liberalism and the Problematic Role of Religion in Modern Societies*
}

\author{
Secularización, liberalismo y el rol problemático de la religión \\ en las sociedades modernas
}

\author{
Sergio García \\ CEDEU Centro de Estudios Universitarios \\ s.garciamagarino@cedeu.es
}

doi: http://dx.doi.org/10.18543/ced-59-2018pp63-73

Contents: I. Introduction.-II. Secularization and secularism.III. The liberal tradition as an unquestioned, invisible framework.-IV. A proposal about the way that social phenomena linked to religion could be approached. $-\mathrm{V}$. The connection between some of the factors identified above and the upsurge of populist right-wing movements.-VI. Conclusion.-VII. References.

\begin{abstract}
This paper argues that there is a defective understanding of the sociological secularization process and a liberal tradition that takes for granted many problematic notions and subtly determines the logic of the debate on religion in modern societies. While the two issues are not causal factors for the rise of radical right-wing populist movements, they constitute the framework within which the debates on ethno-religious pluralism and its relationship with politics take place. These two unresolved questions hinder a good understanding of the complexity of social phenomena related to religion in contemporary Western societies such as fundamentalism, terrorism, political Islam or the claims of other religious groups to participate in the public sphere. In order to achieve the above goals, the article focuses on four interconnected points. The first briefly reviews secularization theory and secularism as an ideology. The second constitutes a questioning of the liberal framework. The third proposes a particular way of approaching those social phenomena linked to religion. The paper concludes broadly examining the factors related to religion that feed right-wing populist movements.
\end{abstract}

Keywords: Secularism, liberalism, right-wing populism, political Islam.

Resumen: Este artículo sostiene que hay una noción defectuosa del proceso de secularización social y que la tradición liberal da por supuesto varios conceptos

* Recibido el 2 de enero de 2018, aceptado el 9 de mayo de 2018.

Cuadernos Europeos de Deusto 
problemáticos que sutilmente determinan la lógica del debate sobre la religión en las sociedades modernas. Si bien estos dos elementos no son factores causales para el auge de los movimientos populistas de extrema derecha, constituyen un marco dentro del cual se dan los debates sobre el pluralismo etno-religioso y su relación con la política. Estas dos cuestiones irresueltas dificultan una comprensión correcta de la complejidad de los fenómenos sociales vinculados a la religión en las sociedades occidentales contemporáneas, tales como el fundamentalismo, el terrorismo, el Islam político o las reivindicaciones de otros grupos religiosos de poder participar en la esfera pública. A fin de alcanzar esos objetivos, el artículo se centra en cuatro puntos interconectados. El primero revisa, brevemente, la teoría de la secularaización y el secularismo como ideología. El segundo constituye un cuestionamiento del marco liberal., El tercero plantea una vía particular de aproximarse a los fenómenos sociales vinculados con la religión. El artículo concluye examinando los factores vinculados a la religión que hay alimentado a los movimientos populistas de extrema-derecha.

Palabras clave: Secularismo, liberalism, populismo de extrema derecha, Islam político.

\section{Introduction}

This paper addresses two issues that are not causal factors for the rise of radical right-wing populist movements, but which constitute the framework within which the debates on ethno-religious pluralism and its relationship with politics take place, namely: a defective understanding of the sociological secularization process and a liberal tradition that takes for granted many problematic notions and subtly determines the logic of the debate.

These two unresolved questions hinder a good understanding of the complexity of social phenomena related to religion in contemporary Western societies such as fundamentalism, terrorism, political Islam or the claims of other religious groups to participate in the public sphere.

In order to achieve the above goals, the article will focus on four interconnected points. The first one will be a short review of secularization theory and of secularism as an ideology. The second will constitute a questioning of the liberal framework. In the third, a particular way of approaching those social phenomena linked to religion will be proposed. And, finally, the factors related to religion that feed right-wing populist movements will be examined more broadly. 


\section{Secularization and secularism}

One of the factors which seems to be related to the lack of capacity to respond effectively to social problems linked to religion is a reductive understanding of how secularization operates in society nowadays.

The theory of secularization is part of the broader theory of modernisation which attempts to explain social change in the following terms. As societies move from traditional to modern entities, different social processes occur: rationalization, the separation of a single social system into differentiated and autonomous subsocial systems, migration from rural areas to cities, bureaucratization of governmental process, secularization... This process took place in Western countries, especially in Europe, but it was considered a universal process, thus modernisation adopted not only a descriptive approach but a teleological one.

Empirically, secularization, in turn, had to do with different phenomena and social processes: the loss of loyalty towards traditional religious institutions, the reallocation of religion from the totality of social system to an autonomous sphere such as politics, science, culture; and, in some cases, the separation of certain traditional religious practices, such as Easter or Christmas, from religious meaning.

However, many people interpreted these facts more radically and, probably going beyond the range of validity of the theory, posited that, as societies become more modern, the influence of religion would disappear or simply become a private issue, a postmodern folklore, exotic cultural rituals or other phenomena which give meaning and generate transcendence such as sports.

In any case, public policies took these conclusions as facts and behaved in consequence, overlooking the role of religion in society and the sociological complex transformations that were taking place at the level of religiosity. In addition, some people took these points as an ideology associated with secularism and made normative statements mentioning that religion should be overcome to move towards more advanced societies.

On the other hand, sociological transformations seemed to be advancing in other ways that have recently been recognized.

To begin with, the role that religious considerations have played in a number of prominent instances of political conflict and revolution is now highlighted. Some examples include the Six-Day War between Israel and Egypt, the Iranian revolution, the development of Hindu nationalism in India and Buddhist nationalism in Sri Lanka, the role of Catholicism in overthrowing communism in Eastern Europe, religious inspired nonviolent civil disobedience movements, the rise of Evangelical politics in the United States and so-called Islamic terrorism, to name a few. 
Recent demographic studies have also been meaningful, showing that the overwhelming majority of the world's population remains just as religious as ever before, if not more so. For example, the World Values Survey, carried out across fifty-six countries from the 1980s to the early 2000s, found that levels of religious belief increased from $80 \%$ to $83 \%$ in the world population during this period. The only region where these levels decreased was Western Europe, and still only from $81 \%$ to $78 \%$. Levels of religious belief alternately increased in Eastern Europe from $68 \%$ to $78 \%$, while the percentage of Chinese who cited "religion" as a major influence in their life grew from $22 \%$ to $36 \%{ }^{1}$.

Other studies have undermined the idea that modernity and religion are somehow at odds by tentatively but empirically proving how religion has played an important role in encouraging many non-Western peoples to accept modern science, modern medicine, and democratic politics ${ }^{2}$. Indeed, the theory of secularization has been challenged in so many ways that numerous prominent thinkers are beginning to claim that it has been falsified outright $^{3}$.

In addition, there is growing recognition of religion as a driving force in the world of social and economic development. For instance, the interdisciplinary field of development shows that certain attitudes towards work and certain worldviews are more conducive to social progress than others; in accordance, a learning in action process is in motion about how to foster those attitudes. This same field of development has underlined the role of faith-based organizations in the provision of social services as well as in the creation of successful development programs ${ }^{4}$.

Furthermore, some of the connections between religion, violence and conflict have been called into question, pointing to the fact that the cause of many conflicts linked to religion is not religion itself, but the fusion of religion with either nationalism or ethnicity or with both ${ }^{5}$.

${ }^{1}$ Daniel Phlpott, Mónica Toft and Timothy Samuel, God's Century: Resurgent Religion and Global Politics, (WW Norton \& Co, 2011): 191.

2 Micklethwait and Wooldridge, God Is Back (Penguin, 2010); Peter van der Veer and Hartmut Lehmann, Nation and Religion. Perspectives on Europe and Asia (Princeton University Press, 1999).

${ }^{3}$ Martin Riesebrot, "Religion in the Modern World: Between Secularization and Resurgence", European University Institute, Max Weber Program, Lecture 2014/1 (2014).

${ }^{4}$ Sergio García Magariño, Gobernanza y religión (Delta, 2016); Séverine Deneulin and Carole Rakodi, "Revisiting Religion: Development Studies Thirty Years On", in World Development, Volume 39, Issue 1, January (2011): 45-54

5 Daniele Conversi, "Globalization, Ethnic Conflict and Nationalism", in Bryan S. Turner and Robert J. Holton, edit., Handbook of Globalization Studies, Edition 1, Chapter 18, (Taylor \& Francis, 2015): 346-366. 
Finally, Europe, against all forecasts, is hosting new religions and new debates as a result of many intertwined processes, such as global integration and migration, delusion with materialistic and hedonistic philosophies and with their promise of a happiness based on the immediate satisfaction of needs, conversions, new forms of spirituality, a renewed search for identity, ecological movements with some features closed to transcendental perspectives, the verification that materialistic ideologies, whether capitalist or communist, have produced inequalities in the first case and totalitarianisms in the latter, the upsurge of a growing debate and a renewed interest in the role of religion in the public sphere or the challenges posed over the public management of religious diversity and of social cohesion within more plural contexts.

\section{The liberal tradition as an unquestioned, invisible framework}

Another reason why social problems linked to religion are so problematic is the assumption of the liberal framework as a neutral value framework. MacIntyre in Competing Rationalities posits that since the Enlightenment, a tradition of inquiry has established its logics in public debate without making explicit its assumptions ${ }^{6}$. Any kind of actor that enters the debate unconsciously assumes these logics. Some of the premises that have been naturalised are the following:

- Liberal partisan democracy is the best system of government.

- The individual is the main entity of social life and political and civil individual rights are the key for progress.

- The separation between the public and the private.

- The relevance of the individual over the community and individual identity over collective identities, which are sometimes considered oppressive.

- There has to be tension between institutions and citizens.

- The notion of power as domination.

- Economy as the axis of social life.

- Competition as the articulating principle for social organization and as the key for excellence.

- The split between religion and politics, faith and reason, mind and heart, rational and emotional.

- Instrumental rationality as the highest form of rationality.

${ }^{6}$ Alasdair MacIntyre, Whose Justice? Which Rationality? (University of Notre Dame, 1988): 388-403. 
- Economic growth as the key for social progress.

- Nature as a resource to be exploded.

- National interest as the main principle for international relationships.

Nonetheless, it is recognised that different ideologies and religious groups come from other traditions of inquiry and depart from different assumptions. The case of political Islamism is paradigmatic. The liberal interpretation of what should be done to integrate Muslim is related to the idea that Islam must experience a modernization process to renounce the political dimensions. The point proposed here is that this is not possible because at the heart of Islam there is a connection between faith and political organisation. Islam without that dimension is not Islam. There are other religious groups, whether Catholic, Evangelical or Protestant, that do not hold this division. What can be done?

There are new peoples, religions and conceptions in Europe, so the framework must be the object of public debate too. These ideas are developed further in the paper "Un cuestionamiento de las bases conceptuales del debate contemporáneo ${ }^{7 "}$.

\section{A proposal about the way that social phenomena linked to religion could be approached}

The approach to address social phenomena linked to religion might have two stages. The first one connects to the effort to try to understand these phenomena using the logics of religion. Then, in a second but important stage, the phenomenon should be addressed from the lens of other explanations.

In order to respond adequately to the public management of diversity or to the threat of ISIS, it is fundamental to advance towards a deeper understanding of what religion is and the social function that it fulfils, taking into consideration its historical influence, identifying clearly when it becomes a source of civilization and when a source of fanaticism. For instance, the strategies to combat radicalization processes often do not take these logics into consideration and end up nurturing radicalization processes in the long term ${ }^{8}$.

7 Sergio García Magariño, "Un cuestionamiento de las bases conflictuales del debate contemporáneo", in Journal of the Sociology and Theory of Religion, Vol. 5, N. ${ }^{\circ} 1$ (2016): 171-190.

${ }^{8}$ Sergio García, "El riesgo de no entender las lógicas de la religión y el fundamentalismo", in Revista Actualidad Criminológica, UCJC, Vol. 3 (2016): 25-30. 
A prerequisite for these responses which pull away from the previous strand of thought is that religious literacy should be included in the public agenda. Society's religious illiteracy is one of the factors which correlates to the prejudices and stereotypes which feed extremist stances.

Secondly, once this analysis using the logics of religion has been done, other perspectives which look at religion in terms of political movements, of collective identity connections, or political legitimising discourses, of any other sorts of fundamentalism should be included.

\section{The connection between some of the factors identified above and the upsurge of populist right-wing movements}

The points highlighted in the above sections are not direct causal factors of the upsurge of the so-called populist right-wing movements. However, they are considered crucial both to prevent their emergence and to respond effectively to them. This last section, on the other hand, will touch upon those factors that seem to be more directly connected to these movements.

The proliferation of religious groups which challenged the statu quo, the intensification of migration processes, the prejudices and social myths that arise out of these factors nurture populisms and increase the receptivity towards their arguments, which are quite connected to the rejection of anything that comes from what they consider odd or strange.

Global integration has also generated different frameworks of reference which feed feelings of disorientation. Right-wing populist movements use a discourse that seems familiar and clear within this atmosphere, so it produces a false sense of security.

The perception of the new penetration of Islam in Europe-although it has been there for centuries - is especially problematic, as Islam is conceived as a "foreign" religion, and people associate it with immigration. That is why most populisms go against Islam. The existence of Al-Qaeda and Daesh serves as a justification for the extreme populist arguments against Islam. Thus, right-wing movements exploit the recourse to fear.

Another point linked to the previous one is the expansion of islamophobia throughout Europe. The higher the islamophobia the easier it is for populist movements to reach people's minds and hearts.

The economic crisis experienced since 2007, and the difficulties in overcoming it, stimulated sectors of society to look for guilty parties. The "others", "the foreigners" who bring "regressive religions" are the cause for all the evils of society. This diagnosis is simpler than the economists' analysis. Ultimately, the populist discourse is quite appealing: the economists, 
the bankers, the elites, could not predict nor prevent the crisis, so their diagnoses are irrelevant. The communication strategy of populisms in this regard was more effective and easier understood: the cause of "our problems" is outside so, by removing them - the immigrants, the Muslim, the foreigners - the problem would be sorted out.

What is considered a crisis of the strict materialistic interpretations of reality, the uncertainties coming from postmodern influences, the increasing complexity of contemporary societies pose a challenge over existential questions. Accordingly, people search for certitudes and populist right-wing movements offer security through dogmatic claims which are simplistic but, as mentioned before, appealing. They say what people like to hear: we are the "good ones", the others are the "evil ones"; we do not have to reflect about our failures since the failures belong to others.

The fact that liberal partisan democracy was incapable of overcoming the economic crisis - among other crises - reduced its legitimacy and nurtured feelings of indignation which have also been channelled by populist movements. In addition, the Enlightenment-inspired critiques against authority opened the door to relativism and the dominion of emotions.

Furthermore, and in connection with what was mentioned at the beginning of the paper, certain sociological transformations, such as the religiosity of people, have not been well understood from traditional political instances. Hence, a progressively wider disconnection between politics and social reality is in motion, as Professor Innerarity points out ${ }^{9}$.

Finally, the logical consequence of a fluid environment of changes, uncertainties, growing pluralism, lack of clear references, fear and superficiality is a renewed search for identity. This search for identity in the absence of solid references is directed towards the only issues that seem to be clear and that underpin populist discourse: ethnicity, simplistic and antagonistic ideology, religion, nationalism and the return to the imaginary homogeneous past and its certitudes.

\section{Conclusion}

The analysis made in the paper first attempts to show that a poor and simplistic understanding of the secularization process might prevent understanding and an effective response to social problems linked to religion such as public management of religious diversity and pluralism.

${ }^{9}$ Daniel Innerarity, Política en tiempos de indignación (Galaxia Gutenberg, 2015). 
Secondly, it was proposed that the liberal framework which limits contemporary debates should be called into question, as its logics and assumptions are imposed over phenomena which must be examined under their own clues and keys. The most paradigmatic example is how to deal with Islam in Europe. The expectation that Islam should be "modernized" to make it fit into Europe is naive and takes for granted that "modernization" means to adjust things to the European way.

Thirdly, it is suggested that social phenomena linked to religion should first be approached under the logics of religion and then using other heuristic perspectives, such as cultural, political, interest oriented, discursive or identitarian studies.

Finally, to complete the picture, the fourth section underlines what are considered some of the primary direct causes driving the upsurge and popularity of right-wing populist movements. As was showed, there are different intertwined factors, most of them linked to either sociological changes as a result of migration, the economic crisis, religious and other social transformations or feelings of rejection that are channelled and exploited through right-wing populist movements' communication strategies.

\section{References}

Conversi, Daniele. "Globalization, Ethnic Conflict and Nationalism". In Handbook of Globalization Studies, edited by Bryan S. Turner and Robert J. Holton, Edition 1, Chapter 18. Taylor \& Francis, 2015.

Deneulin, Séverine and Carole Rakodi. "Revisiting Religion: Development Studies Thirty Years On”, in World Development, Volume 39, Issue 1 (January 2011): 45-54.

García, Sergio Gobernanza y religión, Delta, 2016.

García, Sergio "Un cuestionamiento de las bases conflictuales del debate contemporáneo", in Journal of the Sociology and Theory of Religion, Vol. 5, N. ${ }^{\circ} 1$ (2016): 171-190.

García, Sergio "El riesgo de no entender las lógicas de la religión y el fundamentalismo", in Revista Actualidad Criminológica, UCJC, Vol. 3 (march 2016): $25-$ 30.

Innerarity, Daniel. Política en tiempos de indignación. Galaxia Gutenberg, 2015.

MacIntyre, Alasdair. Whose Justice? Which Rationality? University of Notre Dame, 1988.

Micklethwait, John and Adrian Wooldridge. God Is Back. Penguin, 2010.

Phlpott, Daniel, Mónica Toft and Timothy Samuel. God's Century: Resurgent Religion and Global Politics. WW Norton \& Co, 2011.

Riesebrot, Martin "Religion in the Modern World: Between Secularization and Resurgence", European University Institute, Max Weber Program, Lecture 
(2014/1). Available at http://cadmus.eui.eu/bitstream/handle/1814/29698/ MWP_LS_2014_01_Riesebrodt.pdf?sequence=1\&isAllowed=y

Van der Veer, Peter and Hartmut Lehmann. Nation and Religion. Perspectives on Europe and Asia. Princeton University Press, 1999.

\section{About the author}

Sergio García is a $\mathrm{PhD}$ in Sociology (international mention) at the Public University of Navarra (UPNA), Advanced Diploma on Advanced Studies in Sociology (UPNA), equivalent to the master in pedagogy at the University of the Basque Country (UPV-EHU), Postgraduate course in Education and Social Development (CUB, Colombia) and BA in Physical Activity Sciences and Sport (UPV-EHU). Teaching-researcher at the Camilo José Cela University and the CEDEU / Rey Juan Carlos and associated researcher at the Institute of Democratic Governance (Globernance). He has been a visiting fellow at several universities, including the University of Essex. His main work-lines cover areas such as collective security mechanisms, international conflicts, the Salafist radicalisation process, the new forms of governance, as well as other topics linked with the philosophy and sociology of science and religion. His last works are Desafios del sistema de seguridad colectiva de la ONU: análisis sociológico de las amenazas globales (CIS, 2016), La gobernanza y sus enfoques (DELTA, 2016), Gobernanza y religión (DELTA, 2016), and Introducción a la sociología del crimen (DELTA, 2017) and El desarrollo social y económico: una aproximación holística, (DELTA, 2017). He collaborates with the education and development programmes of the Global Prosperity Studies Institute in Israel, the Rural University of the FUNDAEC (Colombia), the Nur University (Bolivia), the Lazos Learning Foundation in Canada. He is also an analyst collaborator at the Spanish Institute of Strategic Studies at the Spanish Defense Ministry. He is currently directing the Public Affairs Office of the Spanish bahá'í community.

\section{Sobre el autor}

Sergio García es Doctor en sociología con mención internacional en la UPNA, Diploma de Estudios Avanzados en Sociología (UPNA), Equivalente a Máster en Pedagogía (UPV), Posgrado en Educación y Desarrollo Social (CUB, Colombia) y Licenciado en Ciencias de la Actividad Física y el Deporte (UPV). Es profesor-investigador de la Universidad Camilo José Cela y CEDEU / Rey Juan Carlos e investigador asociado del Instituto de 
Gobernanza Democrática (Globernance). Ha sido "Visiting Fellow" de varias universidades, destacando la Universidad de Essex. Sus líneas de investigación engloban los mecanismos de seguridad colectiva, los conflictos internacionales, el proceso de radicalización salafista, las nuevas formas de gobernanza así como otros temas relacionados con la filosofía y la sociología de la ciencia y la religión. Sus últimos libros son Desafíos del sistema de seguridad colectiva de la ONU: análisis sociológico de las amenazas globales (CIS, 2016), La gobernanza y sus enfoques (DELTA, 2016), Gobernanza y religión (DELTA, 2016) y Introducción a la sociología del crimen (DELTA, 2017) y El desarrollo social y económico: una aproximación holística, (DELTA, 2017). Es colaborador de los programas de educación y desarrollo del Instituto de Estudios en Prosperidad Global de Israel, de la Universidad Rural de FUNDAEC (Colombia), de la Universidad Nur (Bolivia), de la Fundación Lazos Learning de Canadá y colaborador analista del Instituto Español de Estudios Estratégicos del ministerio de defensa del gobierno de España. Actualmente dirige la Oficina de Asuntos Públicos de la comunidad bahá'í de España. 


\section{Derechos de autor}

Los derechos de autor (para la distribución, comunicación pública, reproducción e inclusión en bases de datos de indexación y repositorios institucionales) de esta publicación (Cuadernos Europeos de Deusto, CED) pertenecen a la editorial Universidad de Deusto. El acceso al contenido digital de cualquier número de Cuadernos Europeos de Deusto es gratuito inmediatamente después de su publicación. Los trabajos podrán leerse, descargarse, copiar y difundir en cualquier medio sin fines comerciales y según lo previsto por la ley; sin la previa autorización de la Editorial (Universidad de Deusto) o el autor. Así mismo, los trabajos editados en CED pueden ser publicados con posterioridad en otros medios o revistas, siempre que el autor indique con claridad y en la primera nota a pie de página que el trabajo se publicó por primera vez en $C E D$, con indicación del número, año, páginas y DOI (si procede). Cualquier otro uso de su contenido en cualquier medio o formato, ahora conocido o desarrollado en el futuro, requiere el permiso previo por escrito del titular de los derechos de autor.

\section{Copyright}

Copyright (for distribution, public communication, reproduction and inclusion in indexation databases and institutional repositories) of this publication (Cuadernos Europeos de Deusto, CED) belongs to the publisher University of Deusto. Access to the digital content of any Issue of Cuadernos Europeos de Deusto is free upon its publication. The content can be read, downloaded, copied, and distributed freely in any medium only for non-commercial purposes and in accordance with any applicable copyright legislation, without prior permission from the copyright holder (University of Deusto) or the author. Thus, the content of $C E D$ can be subsequently published in other media or journals, as long as the author clearly indicates in the first footnote that the work was published in $C E D$ for the first time, indicating the Issue number, year, pages, and DOI (if applicable). Any other use of its content in any medium or format, now known or developed in the future, requires prior written permission of the copyright holder. 